\title{
OPPORTUNITIES OF DEVELOPING TOURISM INDUSTRY IN BANGLADESH
}

\author{
Mohammad SHAMSUDDOHA \\ Md. Tayub CHOWDHURY \\ Department of Marketing Studies and International Marketing \\ University of Chittagong, Chittagong, Bangladesh
}

\begin{abstract}
Tourism appeal includes natural places like beaches, eco-parks, lakes, valleys, rivers, islands etc., archeological sites, historic mosques and monuments, resorts, picnic spots, forest and wildlife. Bangladesh is a riverine country having attractive panoramic beauty. There are hills, valley, canals, lake, eco-park and mangrove forests, rivers, so many islands and the longest beach in the world. In this country, the scope of nature based tourism, resource based tourism, culture based tourism and eco-tourism is quite evident. Bangladesh is trying hard to develop its tourism industry. Therefore the whole situation deserves to be seen from right perspectives. Role of government is positive since the last twenty years both private and public organizations have come forwarded to attract the local and foreign tourists. The cracks of problem could not identify accurately because of the paucity number of researches and investigations in our country. Developed and organized tourism industry could change the economic condition and contribute a big share in the GDP of Bangladesh. This study will impede the opportunities of developing tourism industry in the light of existing resources.
\end{abstract}

Key words: tourism, development, marketing, Bangladesh

JEL classification: $D 21, L 11, L 83$

\section{INTRODUCTION}

Tourism trends in human society are practices since the prehistoric periods. Tourism in ancient societies developed due to curiosity of individuals to know new things, places and people. Cevat and Dallen (2001) opine that tourism is not only associated with aristocracy. Today even ordinary persons can afford to hang out some places for recreation purpose. With the passage of time, the tourism has become almost a part of our normal life. In the background of its growing popularity, tourism has become a mass phenomenon. People presently practice tourism for the purpose of recreation, business, study, cultural exchanges, promotion trade and commerce, exploration of markets for industrial and agricultural products, searching work, acquisition of knowledge, cultural exchanges, and availing of health service facilities hence many countries developed tourism sector as gainful industry. Bangladesh being a small level flood prone agrarian country 80 percent of which is level floodplain, 8.0 percent is terrace land with patchy forests in central and north-west parts and the remaining 12.0 percent in north, northeast and southeast parts is covered with depleted rain forest. The country is blessed with rich biodiversity with 7,500 species of flowering plants and many species of mammals, reptiles, amphibians and birds. The hills have elevations range of 300-400 meters in Sylhet and Chittagong, 600-700 meters in Rangamati and Khagrchcari districts and in Bandarban the elevation of hills reach unto 15,00 meters (www.theindependentbd.com). The high opportunities of developing tourism industry of Bangladesh are always a priority. Due to lack of capital, Bangladesh government did not able to utilize the golden opportunities. Here, the researcher tried to unearth and remind the tourist places from where tourism industry could be boosted up by any means if some restructuring and reengineering works will be done.

\section{Objectives of the study}

In the light of development of tourism industry in Bangladesh particularly, the main objectives of the study are:

1. To classify different tourist in Bangladesh;

2. To reveal the opportunities of tourism development in Bangladesh;

3. To give some recommendations for the development of tourist industry.

\section{Methodologies of the study}

The study covered various Government and nongovernment organization those who are playing key role in developing tourism industry in Bangladesh. The sample comprised of 100 samples from different region of Bangladesh and all of them collected through convenient way. Necessary secondary information and data were collected from sample respondents through the direct interview and observation method. In addition, the study reviewed of all the tourism related websites for updated information. On the other hand, the researcher also reviews several foreign and local research works as well in this field. 


\section{LITERATURE REVIEW}

Bangladesh is situated on the north-eastern side of the South Asian subcontinent and is bordered by India in the east, west and north; by a small part of Myanmar in the south-east and by the Bay of Bengal in the south. Bangladesh is mainly a flat alluvial plain, criss-crossed by the world's three mighty river systems, namely the Padma, the Jamuna and the Meghna and their innumerable tributaries. The marketing experts opine that tourism marketing is the systemic and coordinated efforts to optimize the satisfaction of tourism. Generally speaking, tourism planning has been defined as a process based on research and evaluation, which seeks to optimize the potential contribution of tourism to human welfare and environmental quality (Tosun, Jenkins, 1998). Thus, tourism planning should relate tourism development to the more equitable distribution of wealth that is one of the main aims of national development planning. In this respect, tourism planning is a component of national development planning and strategy. Moreover, it includes a decision-making process between the tourism industry and other sectors of the economy, between various subnational areas and between types of tourism. It requires the integration of the tourism industry into other sectors such as agriculture, industry, transportation and social services (Timothy, 1999). The conceptual exposition appears essential to study tourism marketing. The marketing experts opine that tourism marketing is the systemic and coordinated efforts to optimize the satisfaction of tourism. The thing here is concerned with making availability to the tourist organizations. The tourism marketing is also supposed to be a device to make a possible reorientation in the business policy and overhaul in the management concept. Tourism marketing is an integrated effort to satisfy tourists by making available to them the best possible services. It is a device to transform the potential tourists into actual tourists. It is the safest way to generate demand and expand market. Further it is an effort to make possible harmony between the social interests and interests of tourist organizations. It is an approach to promote business, which feeds the organizations the necessary information for farming or revamping the marketing decisions. The tourisms marketing is thus promotion or sales based on research on what are to be sold in the market. Dependence on laurels is not possible in the tourism marketing since the taste preferences of users change very firstly in Bangladesh.

The above literature shows that there is not plethora research work based on tourism industry in Bangladesh. It is evident that lack of consciousness, security and information is the main problem with the tourists of Bangladesh. Thousands of places are very outstanding and comparable with international tourist places but unfortunately it never be focused through proper channels towards local and international tourists to attract to visit here. This is why, researcher tried to focus important tourists places towards all kind of tourists, decision and policy makers, readers and stakeholders for the sake of availing the opportunities to develop the tourism industry in Bangladesh.

\section{THE USERS OF TOURISM SERVICES}

There are several users of tourist like rural tourists, urban tourists and international tourists. For the successful execution of marketing strategies for translating the strategies in to meaningful purposes, it is essential to have a detailed knowledge of users of services. Tourists coming from the rural areas are rural tourists whereas the tourists coming from urban areas are urban tourists.

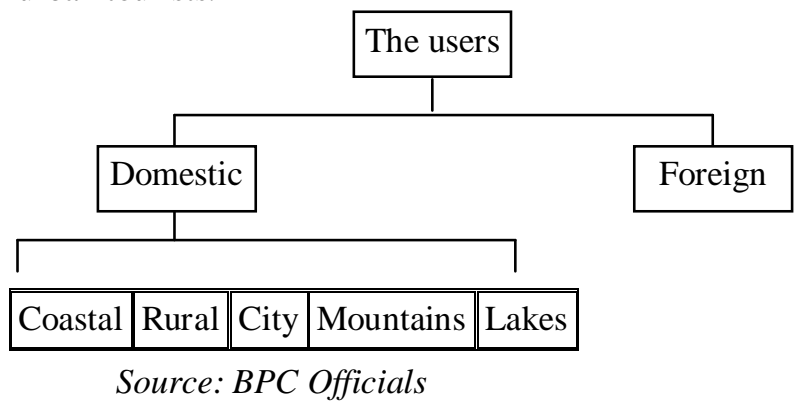

\section{Classification of tourists}

According to a sample survey, the tourists' arrivals are classified in the following categories:
A. Business - $42 \%$
B. Pleasure - $23 \%$
C. Official $-18 \%$
D. Others $-17 \%$
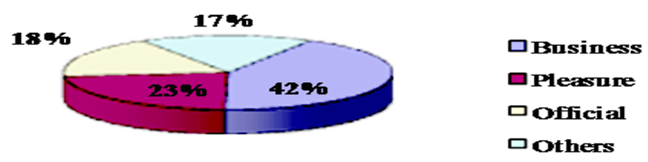

Figure 1 - Shows the Arrival of Tourists

Source: Bangladesh Parjatan Corporation

\section{OBJECTIVES OF TOURISM DEVELOPMENT}

Tourism, as the worldwide initiator of movements of people and exchange of cultures, has become the world's single largest industry. It has matured, provides the livelihood for many millions, foments good will between nations, provides a display case for a nation's products and stimulates creative and enjoyable activity. The objectives and perceived benefits of tourism for Bangladesh are specific. They are:

- To improve the balance of payments and to reverse negative flow in the tourism sector;

- To provide employment;

- To capitalize on the investment already made in airports, the nationals airline, in transport and accommodation;

- To enhance the image of the country in the eyes of the world; 

country;

- To reinforce and protect the culture of the

- To expose its people to world movements, the stimulation provided by other cultures and enhances their employment potential abroad;

- To enable its people to share in the enjoyment of facilities and amenities that would be created for international tourism purposes and that would provide a base for growth in domestic tourism.

\section{OPPORTUNITIES TO DEVELOP INTERNATIONAL STANDARD TOURIST PLACES}

Bangladesh has lots of tourist places which have never been publicized by the government and other agencies. People do not aware of the beauty and variety of the different tourist spots in Bangladesh. Here the researcher wanted to focus on different tourist areas or spot which has tremendous prospect to introduce as an international standard tourist spot with required facilities. These all are able to amuse, recreate and entertain people certainly. Some of the special spots are mentioned in following way:

1. Cox's bazaar: The world's longest $(120 \mathrm{~km}$.) beach sloping gently down into the blue water of the Bay of Bengal. Cox's Bazar is one of the most attractive tourist spots of the country. There are more tourists places around cox's bazaar which are as follows:

Spots of Cox's Bazar

a. Inani: Inani is also a beach which is connected with the Cox's Bazar beach and $30 \mathrm{~km}$ away from the city. Here the tourists will find sea shore, hills in the behind, coconut trees and amazing sunset.

b. Himchhari: A beauty spot in the solitude of the sea and the hills.

c. Ramu: A small Buddhist village Ramu is $15 \mathrm{~km}$ away from Cox's Bazar.

d. Moheskhali Island: The island is dotted here and there with forested hills and beach with the ancient Adinath Temple. Number of Fishermen and the Rakhyne villages are enormous attractions of the island.

e. Sonadip: This is a maiden island of Cox's Bazar across the Bay. Under the wide open blue sky fishing community, dry fish processing and colonies of the red sea crabs are attractions of the island.

2. Kuakata: Kua meand well, Kata means dug. Kuakata have long wide seashore in distinctive nature surroundings, rising from the sea and set into it, attractive fairs and Hindu festivals during 'Rush Purnima' and 'Maghi Purnima', different Tribal communities' festivals, primordial Buddhist temple, migratory birds in the winter seasons and natural forests with coconut and palm trees.

3. Sundarbans: The Sundarbans is the largest mangrove forest in the world with total areas of 5772.85 sq.km. Thousands of canals creeping around and more than ten thousand islands swell and sink with the tide in the bay. Number of island, sea water, canals, deep forests, royal Bengal tigers, spotted deer, millions of different species like birds, monkey, dolphin etc. and mangroves together support an eco-system at once unique and sprightly develop the Sundarbans into a invaluable resources of biodiversity. The most beautiful attractions are Hiron Point, Kotka, Kochikhali, Dubla Island, Mandarbaria, Putney Island and Tinkona Island.

4. Saint Martin's Island: St. Martin's island is a small island in the northeast part of the Bay of Bengal, about $9 \mathrm{~km}$. south of the Cox's Bazar-Teknaf pleasure trip in the southernmost part of Bangladesh. The local people call it Narikel Jinjira. There are two small dead lagoons and a stretch of marshy land in Dakshinpara. Another most attractive place in Saintmartin is Chera dwip which is a part of St. Martin's Island but divided during tides. One can go to chhera-dwip by walking during low tide.

5. Sylhet: Sylhet, a land of devotion and nature's bounties is in the north-east of Bangladesh. A hilly region in mainly a plain country Sylhet lies between Khasia and Jaintia Hills in the north and Tripura Hills on the south. Forest around abound with innumerable birds species. The orange grove of Chhatak with humming bees adds to the fairy-land aura of the region. The Sylhet vally is formed by a beautiful, winding pair of rivers named the Surma and the Kushiara both of which are fed by innumerable hill streams from the north and the south. Sylhet is the foremost tea granary of the country. Different tourists attraction of Sylher are as follows:-

a. The Shrine of Hazrat Shah Jalal (R.A.) and Shah Paran (R.A.): Both came here to disseminate the message of Islam.

b. Jaintipur: It is renowned as a capital of an ancient Kingdom includes the Khasia and Haintia hills and the plains of Jaintia to this day hold the ancient aura of the kings and queens.

c. Shahi Eid Gha: The Shahi Eid Gha was built on a hill by the Mughal Emperor Aurangzeb.

d. Madhabkuunda: Famous for its fascinating waterfall, Madhabkunda attracts a large number of visitors every year. Bangladesh Parjatan Corporation offers restaurant, retiring room, picnic and parking facilities for the visitors there.

e. Monipuri (Tribal) dance: Several tribes lives in the area each distinct from the other in their life and living. The Monipuri dance is known and appreciated every where.

f. Handicrafts: The superb pieces of Sylhet handicrafts and furniture decorate many homes.

g. Tanabil - Jaflong: It's a waterfall from high hills and amazing beautiful place with hills and green. Stone rolling down the sides of hills or to the plains is a observer's delight.

h. Srimongal: This place is prominent for large tea gardens in smoothing and comfortable climate conditions. Srimongal is the coolest place in Bangladesh. Several mining industry is also situated here.

6. Lawachhara: Lawachhara the second largest artificial reservoir of biodiversity on 1250 hector area, was planned in 1922 by the British. Over the period, it has become a residence of rich biodiversity and now it turned to Lawachhara national park.

7. Bandarban: $92 \mathrm{~km}$ from Chittagong city by mountainous road through the green forest and the hills is tucked away quiet haven. This hidden paradise away from 
the din and bustle of the world is called Bandarban. Bandarban has the unique privilege of having two highest peaks of the country, the Keokeradong and Tajingdong that measure up to 4000 and 4632 feet respectively. The panoramic view of Bandarban will surely allure tourists to extend their stay, roaming around in the natural wilderness of these hilly districts.

a. Boga Lake: The Boga Lake attracts tourist because of its picturesque beauty but it is out-of-the-way by motorized transports.

b. Chimbuk hill: Chimbuk is a unique hill having $2000 \mathrm{ft}$. high from the sea level. Here Sangu river give a thrilling experience in the lifetime.

c. Meghla: The Meghla tourist spot is situated at about $6 \mathrm{~km}$. near Chitagong -Bandarban highway. A beautiful hanging wooden bridge enhances the beauty of the spot.

d. Buddha Dhatu Jadi: It is an attractive temple located at $300 \mathrm{ft}$. highest on a hill at Balaghata $2 \mathrm{~km}$. from Bandarban.

e. Alikandam: There are numerous settlements of Murang and Khumi tribal people in the area. Ali's tunnel is also situated here. There are many mysterious tales regarding this tunnel.

f. Rijuk water fall: This natural mighty water fall is situated at Ramu. Here, there are the water incessantly falls into the river Sangu for about $300 \mathrm{ft}$. high hill dazzling like pearl particles in the space creating an un parallel beauty of nature.

8. Dhaka Sonargoan: The golden village of Bangladesh, is a historical township situated about $25 \mathrm{~km}$. southeast of Dahka. It is generally belive that "subarnagran" the other name of the place, had existed from the time of Pala and Deva king who had used it as their administrative town. Isha Khan, the Masnad- I- Ala, had also built his army headquarter here. There are a number of old historical object and architectural remains such as the tomb of Sultan Giasuddin Azam Shah, the single-domed mosque of Mograpara,Goladi mosque, tomb of Munna Shah Darbesh, tomb of Ponakai Diwana, Panch Pir Dargh and the single-domed squire mosque built by Sultan Jalaluddin Fateh Shah.

9. Chittagong: is Bangladesh's main seaport and its second-largest city which was built on the banks of the Karnaphuli River, and its ends nearby, in the Bay of Bengal. Being the country's primary port, Chittagong is the main route for almost all of Bangladesh's import and export, generating a major portion of the country's annual revenue and being its commercial centre. Its harbour contains extensively developed port facilities and is particularly suitable for ocean steamers. Two large environmental centres ("ecoparks"), catering to ecology and forestry-related research, have recently been built in neighboring Sitakunda and Bashkhali.

10. Rangamati: Rangamati is located in the Chittagong Division. The total area of the district is $6116.13 \mathrm{sq} \mathrm{km}$. It's a combination of Hill- Lake-Plain land.

11. Kaptai: Kaptai is a region in south-eastern Bangladesh. Karnaphuli Hydroelectric Power Station, the only Hydro-electric power plant of Bangladesh is located here. The Kaptai Dambuilt for this purpose on the Karnaphuli River created the Kaptai Lake, the largest man-made dam in Bangladesh. The plant not only plays an important role in meeting the power demand of the country but is also vital as a flood management installation for the areas downstream.

12. Rajshahi: Rajshahi district was a part of the Pundra region of ancient Bengal. The capital of Vijay Sen, the king who led military operations in Sri Lanka and Southeast Asia was located 9 miles $(14 \mathrm{~km})$ to the west of Rajshahi town.

13. Sitakunda Chandranath Hindu Temple: It is approximately $37 \mathrm{~km}$ far from Chittagong city. This is famous for Chandranath Hindu Temple - one of the oldest temples in the subcontinent. There is also Buddhist Temple having a footprint of Lord Buddha. These places particularly the hilltops are regarded as very sacred by the hindus and buddhist. Shiva Chaturdashi (14th) festivals is held every year in February when thousands of pilgrims assemble which lasts for ten days. There is also a hotwater spring $5 \mathrm{~km}$ to the north of Sitakunda.

Besides that Maynamoti, Kotbari, Dulhazra ecopark, Sitakunda eco park, Banskhali eco park, Thousand of historical tombs, lots of island like Sandip, Nizum Deep, Hatiya, numbers of historical mosque, Mogal made offices, roads, buildings, mosque, temple etc. are spreading out all over the country.

\section{RECOMMENDATIONS}

There are so many problems, the researcher found regarding tourism in Bangladesh. The customers of tourism market are price sensitive and want security in tourist place. To expand the market it is necessary to set competitive price.

- Develop the management education on tourism Marketing and prepare marketing or sales people to sell the product properly to the right place in local and global perspectives as well.

- In order to strengthen the marketing department, a person should be appointed to look after policy matters and new brand exclusively while the responsibility of that division should be in the hand of the marketing Director.

- Bangladesh Parjatan Corporation should create pressure on Govt. to implement her policy more strictly regarding the quality of service. As a result private service provider will be able to face competition on an even ground.

- To deliver information to the foreign tourist through online or website and Information Technology is necessary to research about new tourist spot.

- To encourage the Jr. executives they should be promoted to his/her position and new executives should be recruited to ensure.

- Training and other refresher courses should be conducted at regular intervals to up date the personnel with efficient. 


\section{[Nr. 8]}

- BPC should formulate her strategy in such to way by which she can serve the users more effectively. BPC can easily utilize the following distribution channel.

- Private sector in this field should be encouraged by the BPC and as well as Government officials.

\section{CONCLUSION}

Bangladesh is one of the third world countries having scarcity of his finance but they can increase their GDP through by giving stress to the tourism industry. From overall point of view, Bangladesh Parjatan Corporation is a only one government tourism service provider firm in Bangladesh, which practices modern marketing concept. But in some sector they are lagging behind. There have a lot of opportunities to earn foreign and local revenue from this sector but this sector is totally ignored. The researcher has put forward some recommendation. If BPC follows these recommendations, in the long run, BPC will become revenue-generating organization. Bangladesh has a lot of potential tourist spots but it should do find out the exposure. Otherwise, she cannot cash from this potential sector. And private sector should encourage by the government to work together for the sake of the development of tourism industry in Bangladesh.

\section{BIBLIOGRAPHY}

1. Kotler, P., Armstrong, G. (2003) Principles of Marketing. $7^{\text {th }}$ Edition.

2. Nelson, J.G., O’Neil, P.C. (1990) Tourism-historical and conceptual context. A Workshop on a Strategy for Tourism and Sustainable Development, pp. 15-19, Heritage Resources Centre, University of Waterloo, Waterloo.

3. Timothy, D. (1998) Cooperative tourism planning in a developing destination, Journal of Sustainable Tourism, Vol. 6 No. 1, pp. 52-68. 352.

4. Tosun, C., Dallen J.T. (2001) International Journal of Contemporary Hospitality Management. Vol. 13. No. 7. Page.

5. Tosun, C., Jenkins, C.L. (1998) The evolution of tourism planning in third world countries: a critique. Progress in Tourism and Hospitality Research, Vol. 4 No. 2, pp. 101-14.

6. *** (2004) Asian Development Bank (ADB), TA No. 6131-STU: South Asia Subregional Economic Cooperation (SASEC) Tourism Development Plan, Final Report, August 2004.

7. *** (1994) Conference Summary and Final Report, Center for Global Change, University, of Maryland at College and the Japan Foundation Center for Global Partnership, Washington, DC, 1-2 December 1994.

8. *** (1995) Govt of Bangladesh, National Tourism Policy 1992, and National Industrial Policy.

9. http://www.bangladeshonline.com

10. http://www.bangladeshonline.com/tourism/spots

11. http://www.banladeshtourism.gov.bd

12. http://www.ilo.org/

13. http://www.parjatancorporation.org

14. http://www.tourismindiaonline.com

15. http://www.tourismindia.com

16. http://www.theindependent-bd.com/details.php?nid=149279

17. http://www.undp.org/

18. http://en.wikipedia.org/wiki/Rangamati_Hill_District

19. http://www.wto.org/ 